\title{
BILATERAL LACERTUS FIBROSUS ENTRAPMENT OF MEDIAN NERVE AT THE ELBOW (LACERTUS SYNDROME)
}

Ishikhov $\mathrm{IM}^{1}$, Kolomiets KV ${ }^{1}$, Gamidov FM² , Gantsgorn EV ${ }^{1} \otimes$

${ }^{1}$ Rostov State Medical University, Rostov-on-Don, Russia

${ }^{2}$ Clinical Hospital "Railways-Medicine”, Rostov-on-Don, Russia

\begin{abstract}
Lacertus fibrosus entrapment of the median nerve at the elbow, or Lacertus syndrome, is a rare pathology, which is difficult to detect by instrumental examination methods. Literary sources provide no information on the syndrome prevalence, as well as on precise diagnosis and treatment algorithms, which makes it difficult to establish the diagnosis and appoint the effective treatment. Lacertus syndrome is characterized by positive scratch collapse test; differential diagnosis is required to distinguish it from carpal tunnel syndrome. Clinical case of bilateral lacertus fibrosus entrapment of the median nerve at the elbow is reported, Lacertus syndrome diagnosis criteria and surgical treatment method are set out. The results of the surgical tactics used are as follows: pain, paresthesia and numbness in the innervation field of the median nerve have vanished, the muscle strength has been restored to level M5 in accordance with MRC muscle strength scale. These results demonstrate high efficiency of the proposed lacertus syndrome surgical treatment.
\end{abstract}

Keywords: median nerve entrapment, Lacertus syndrome, bicipital aponeurosis, lacertus fibrosus

Author contribution: Ishikhov IM — study concept, literature analysis, data interpretation, manuscript writing; Kolomiets KV — literature analysis, data interpretation; Gamidov FM - patient's treatment and follow-up, manuscript writing; Gantsgorn EV — data interpretation, manuscript editing.

Compliance with ethical standards: the informed consent for surgery and personal data processing was obtained from the patient.

$\triangle$ Correspondence should be addressed: Elena V. Gantsgorn

6-ya liniya, 65, Rostov-on-Don, 344019; gantsgorn@inbox.ru

Received: 16.03.2021 Accepted: 10.04.2021 Published online: 25.04.2021

DOI: $10.24075 / \mathrm{brsmu} .2021 .016$

\section{БИЛАТЕРАЛЬНАЯ КОМПРЕССИЯ СРЕДИННОГО НЕРВА АПОНЕВРОЗОМ ДВУГЛАВОЙ МЫШЦЫ ПЛЕЧА НА УРОВНЕ ЛОКТЕВОГО СУСТАВА (ЛАЦЕРТУС-СИНДРОМ)}

И. М. Ишихов ${ }^{1}$, К. В. Коломиец ${ }^{1}$, Ф. М. Гамидов ${ }^{2}$, Е. В. Ганцгорн ${ }^{1} ه$

1 Ростовский государственный медицинский университет, Ростов-на-Дону, Россия

${ }^{2}$ Клиническая больница «РЖД-Медицина», Ростов-на-Дону, Россия

Компрессия срединного нерва апоневрозом двуглавой мышцы плеча (lacertus fibrosus) на уровне локтевого сустава, или Лацертус-синдром, - редкая патология, которую сложно обнаружить с помощью инструментальных методов исследования. В литературе отсутствуют сведения о распостраненности данного синдрома, четкие алгоритмы его диагностики и лечения, что затрудняет постановку диагноза и назначение эффективного лечения. Лацертуссиндром сопровождается положительным scratch collapse test и требует дифференциальной диагностики с синдромом карпального канала. Представлен клинический случай пациента с билатеральной компрессией срединного нерва апоневрозом двуглавой мышцы плеча на уровне локтевого сустава, изложены критерии диагностики Лацертус-синдрома, способ оперативного лечения. Результаты использованной хирургической тактики: исчезновение боли, парестезий и онемения в зоне иннервации срединного нерва, восстановление силы мышц до уровня М5 по Шкале оценки мышечной силы MRC - свидетельствуют о высокой эффективности предлагаемого хирургического лечения Лацертус-синдрома.

Ключевые слова: компрессия срединного нерва, Лацертус-синдром, апоневроз двуглавой мышцы плеча, lacertus fibrosus

Вклад авторов: И. М. Ишихов - концепция исследования, анализ литературы, интерпретация данных, подготовка рукописи; К. В. Коломиец - анализ литературы, интерпретация данных; Ф. М. Гамидов - лечение и наблюдение пациента, подготовка рукописи; Е. В. Ганцгорн — интерпретация данных, редактирование текста.

Соблюдение этических стандартов: от пациента получено добровольное информированное согласие на оперативное лечение и обработку персональных данных.

$\bigotimes$ Для корреспонденции: Елена Владимировна Ганцгорн

ул. 6-я линия, д. 65, г. Ростов-на-Дону, 344019; gantsgorn@inbox.ru

Статья получена: 16.03.2021 Статья принята к печати: 10.04.2021 Опубликована онлайн: 25.04.2021

DOI: 10.24075 /vrgmu.2021.016

Traditional wisdom is that proximal median nerve entrapment (PMNE) at the level of the elbow is a rare diagnosis, since it is difficult to detect using such electrophysiological techniques as electroneuromyography (ENMG) [1]

In foreign literature the disorder is referred to as Lacertus syndrome (LS). The detailed description for this syndrome was first provided in 2013 by Elisabet Hagert (Sweden), who also proposed a method for LS diagnosis based on the following clinical manifestations: weakness in muscles innervated by the median nerve distal to the lacertus fibrosus (LF), i.e. in flexor hallucis longus, flexor digitorum profundus II, and flexor carpi radialis; pain upon pressure over the median nerve at the level of the LF; positive scratch collapse test [1]. Later, this criterion contributed to a more frequent LS detection in patients of different age groups, and to more accurate differential diagnosis to distinguish LS from carpal tunnel syndrome, which often has similar clinical manifestations.

However, there are still just a few papers on the issue in medical literature, which hinders wide dissemination of knowledge on differential diagnosis and treatment of LS among doctors of different specializations, and makes it almost impossible to assess the prevalence of LS in certain countries. To date, no publications on the lacertus fibrosus entrapment of the median nerve at the elbow can be found in domestic sources, which accounts for lack of favorable outcome in treatment of patients with such pathology. 
The clinical features of the syndrome are relatively nonspecific (episodes of numbness, paresthesia in the innervation field of the median nerve, pain in the area of lacertus fibrosus, loss of strength in flexor hallucis longus, flexor digitorum profundus II, and flexor carpi radialis), the disorder shares some similarities with carpal tunnel syndrome [2, 3]. Therefore, the patients may show no treatment effect for a long time.

The paper reports a clinical case of LS; diagnostic approach and tactics of surgical treatment for patients with clinical signs of median nerve entrapment are being proposed.

\section{Clinical case}

Patient A. aged 32, was admitted to Clinical Hospital "RailwaysMedicine", Rostov-on-Don, because of the decreased first three fingers flexion strength, numbness, creeping sensation in the palmar surface of the first three fingers on both hands, which intensified during computer work and any physical work involving hands. The patient denied any injuries to his left and right upper limbs.

According to the patient, numbness and weakness in the fingers had emerged for the first time 6 years before in the right hand. Then similar symptoms emerged in the left hand. Loss of sensitivity in the first three fingers, as well as rapid loss of the thumb and index finger strength were the first symptoms of the disorder, which occurred while playing games using joystick forcing the patient to quit the game. These symptoms vanished after a few minutes of rest, but kept coming up each time he played games. Subsequently, the symptoms progressed: they occurred during computer work and guitar playing. After neurological assessment, instrumental examination was recommended: magnetic resonance imaging (MRI) of the cervical spine, electroneuromyography (ENMG) of the upper limbs, ultrasonography along the entire length of the median nerve. MRI revealed no degenerative/dystrophic changes in the cervical spine; ENMG detected no upper limb peripheral nerve pathology; ultrasonography revealed sonographic signs of bilateral carpal tunnel syndrome, as well as sonographic signs of flexor tendinitis. The diagnosis of bilateral carpal tunnel syndrome was established based on the examination results. Conservative treatment consisting of non-steroidal anti-inflammatory drugs (NSAIDs), anticonvulsants, B vitamins,

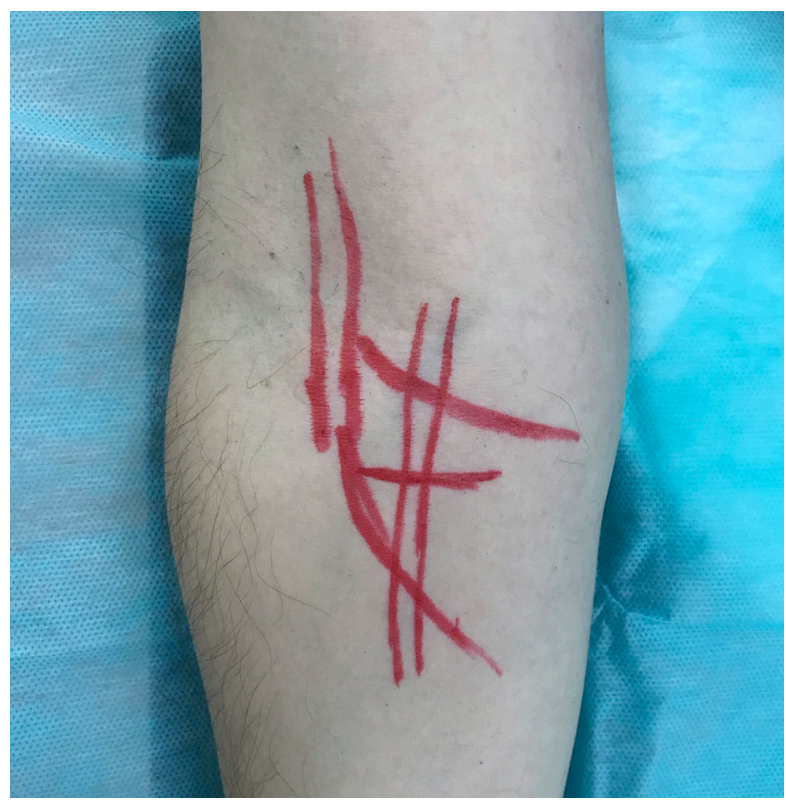

Fig. 1. Preoperative markup massage of the upper limbs, physiotherapy (phonophoresis with hydrocortisone applied over the wrist joints № 10, exercise therapy, acupuncture) was prescribed. During treatment the patient noted that only regular exercise therapy could produce some improvement. Lack of significant improvement made the patient to contact hand surgeon.

Examination of the left and right upper limbs revealed no visible changes. Palpation elicited pain in the area of the LF ligament. During hand pronation, paresthesias in the first three fingers along the palmar surface were observed. Resistive testing revealed loss of strength in flexor hallucis longus, flexor digitorum profundus II, and flexor carpi radialis, which corresponded to M3 criterion ("The muscle can move the joint it crosses through a full range of motion against the gravity but without applying any resistance") of the Medical Research Council Weakness Scale (MRC) [4]. Scratch collapse test was positive above the LF ligament. The testing method is as follows [5]: the patient sits down facing the surgeon with elbows flexed and forearms extended, his wrists in a neutral position. Step 1: the patient resists bilateral shoulder adduction (internal rotation of the forearms) performed by the surgeon. Step 2: the surgeon "scratches" the skin or runs his fingers along the projection of entrapped median nerve at the level of lacertus fibrosus. Step 3: the surgeon immediately repeats Step 1. A positive response to scratch collapse test is a temporary loss of external resistance. Tinel's sign, Durkan's compression test and Phalen's test were negative, which made it possible to exclude carpal tunnel syndrome. Active movements of upper limb joints were performed over full range of motion. No vascular dysfunction was observed at the time of examination. The following clinical diagnosis was established: G56.1 Other lesions of the median nerve.

Surgical treatment was recommended: ligamentotomy of the LF ligament, decompression of median nerve in the left and right upper limbs.

\section{Surgical technique}

At the first stage of the procedure it was necessary to differentiate LF. For that, we identified the distal biceps tendon and found a dense ligament woven into the deep fascia of the forearm to the medial side of the distal biceps tendon by

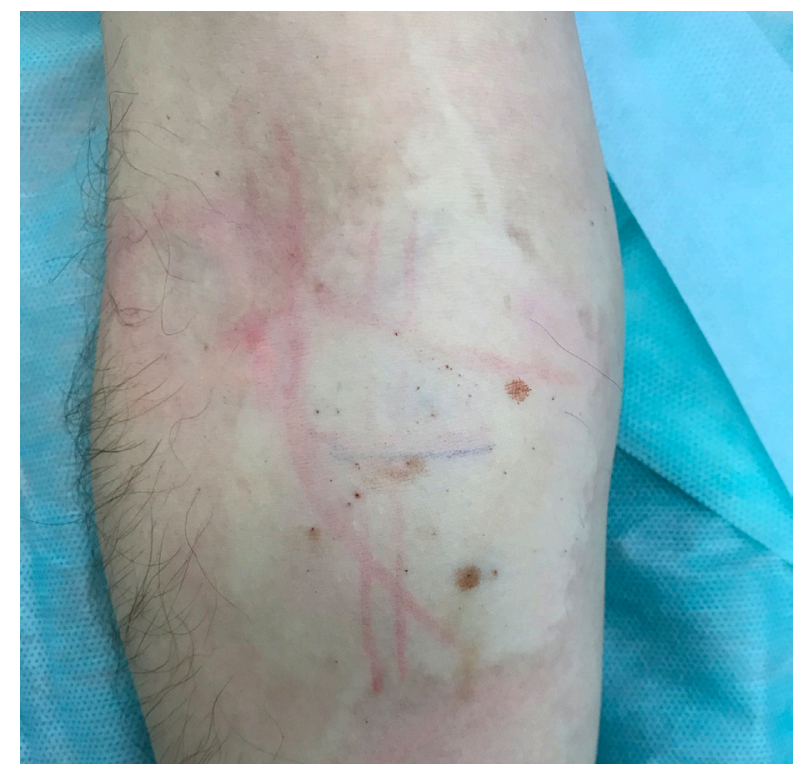

Fig. 2. WALANT (Wide-Awake Local Anesthesia No Tourniquet) local infiltration anaesthesia 
palpation. Incision was planned over the ligament. Preoperative markup is presented in Fig. 1.

The surgical procedure was performed in an outpatient setting under WALANT local infiltration anesthesia (Fig. 2).

For that the patient was anesthetized 20 min preoperatively using $20 \mathrm{~mL}$ of $1 \%$ lidocaine $(10 \mathrm{mg} / \mathrm{mL})$ with $0.2 \mathrm{~mL}$ epinephrine $(5 \mu \mathrm{g} / \mathrm{mL})$ and $2-3 \mathrm{~mL}$ of sodium bicarbonate buffer $(50 \mathrm{mg} / \mathrm{mL})$ used to stabilize the lidocaine $\mathrm{pH}$.

A 2-3 cm transverse incision was placed $2-3 \mathrm{~cm}$ aside from the flexion crease of the cubital fossa, $1-2 \mathrm{~cm}$ medial of the biceps tendon (Fig. 3). The skin incision was placed parallel to flexion elbow crease, which ensured good postoperative aesthetic appearance. Careful dissection was made subcutaneously to identify the medial antebrachial cutaneous nerve, which can occasionally be found in the zone of access before it reaches the pronator teres fascia. The pronator teres fascia was incised and slightly retracted medially. LF was easily visualized in the center (Fig. 4) and dissected in the transverse direction of fiber orientation. After dissection of LF the median nerve was identified, sometimes housed in the pronator teres muscle belly (Fig. 5).

The resistive testing was performed prior to skin closure, since the muscle strength is usually restored immediately after the release of the nerve [6]. Active flexion with overcoming resistance of flexor hallucis longus, flexor digitorum profundus $\mathrm{II}$, and flexor carpi radialis had fully recovered. After hemostatic procedures, subcuticular suturing was performed with 4-0 monofilament suture (Fig. 6). Sterile dressing was applied. Immobilization was not required.

The patient returned to normal routine 2 days after surgery. He was advised to avoid lifting of loads heavier than $1 \mathrm{~kg}$ during the first 2 weeks, as well as to avoid physical exercise. Heavier loads and physical work were permitted 4 weeks after surgery.

\section{Discussion}

Clinical manifestations of LS vanished intraoperatively after the median nerve decompression. Muscle strength in flexor hallucis longus, flexor digitorum profundus II, and flexor carpi radialis recovered completely, which fulfilled the M5 criterion ("The muscle can move the joint it crosses through a full range of motion, against the gravity as well as against full resistance applied by the examiner - Normal power") of the MRC scale.

A month after the procedure the scratch collapse test became negative; numbness, and creeping sensation in the palmar surface of the left and right hand first three fingers resolved completely. During the postoperative period the patient experienced two episodes of short-term dull pain in muscles of forearm and palm, and voiced no other complaints. The scar is pink and painless, with no adhesions.

Two months after surgery on his right hand the patient underwent similar surgical procedure on his left hand. After 3 months the patient returned to normal routine and got a job (undiagnosed LS and ineffective conservative treatment made him unable to work for almost 5 years).

Similar favorable results of the applied LS surgical treatment method (particularly, in terms of muscle strength recovery) have been reported in the paper by E. Hagert (2020): after surgery the patients, advised to limit physical activities for some time, return to light duties within 1-2 days [6].

\section{Conclusion}

The clinical case reported demonstrates the importance of raising awareness about clinical manifestations, diagnosis

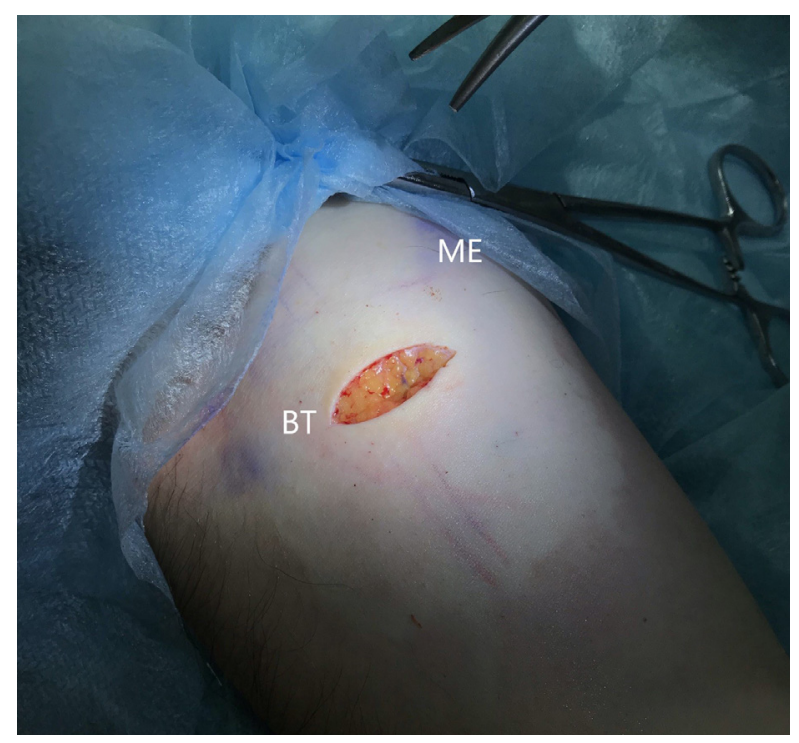

Fig. 3. Incision. BT — biceps tendon; ME — medial epicondyle

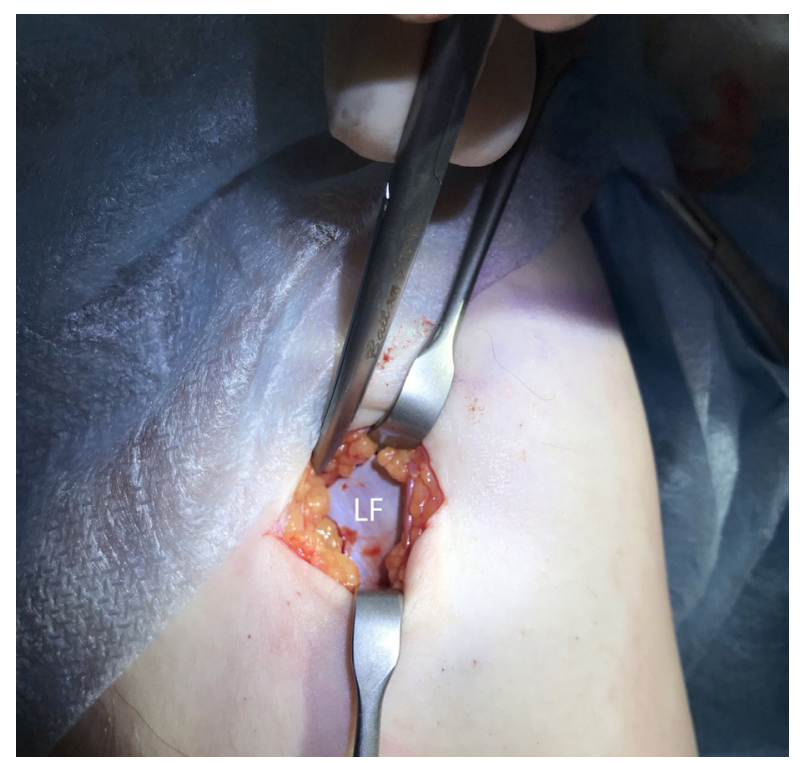

Fig. 4. Lacertus fibrosus (LF) ligament is carefully isolated and divided in its entire length

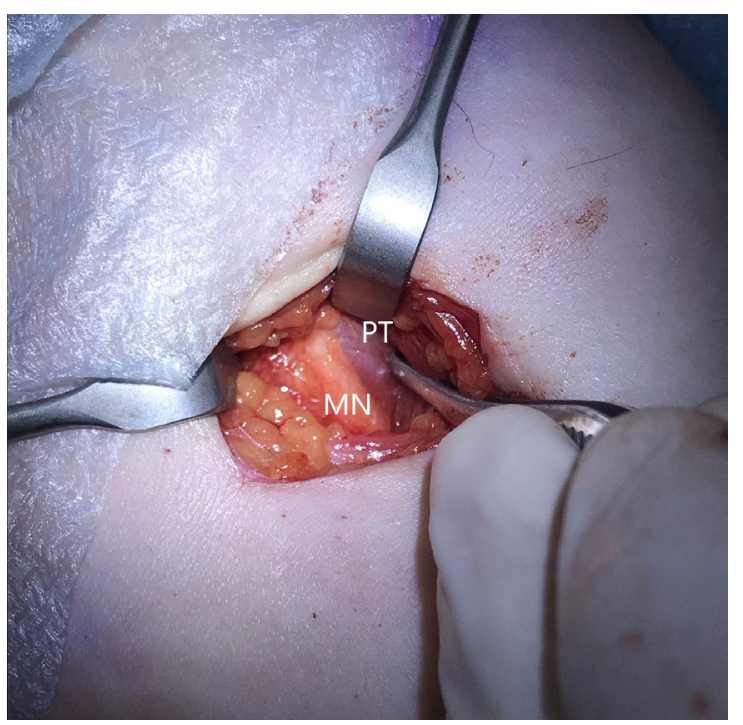

Fig. 5. Median nerve is easily seen after LF division. MN — median nerve; PT pronator teres 
methods and surgical treatment of LS. In this example the diagnosis was established based on the following clinical signs combination: weakness in muscles innervated by median nerve distal to LF (flexor hallucis longus, flexor digitorum profundus II, and flexor carpi radialis); pain elicited by pressure on the median nerve at the level of LF; positive scratch collapse test and negative compression tests. We believe that it would be appropriate to recommend taking into account the stated diagnosis criteria when examining patients with clinical manifestations of median nerve entrapment. Correct differential diagnosis of LS makes it possible both to avoid appointment of unnecessary conservative therapy (particularly, of NSAIDs and anticonvulsants), and to provide timely delivery of adequate surgical care allowing to ensure patients' recovery and the quality of life improvement as quickly as possible.

\section{References}

1. Hagert E. Clinical diagnosis and wide-awake surgical treatment of proximal median nerve entrapment at the elbow: a prospective study. Hand (NY). 2013; 8 (1): 41-46.

2. Bland JD. Carpal tunnel syndrome. BMJ. 2007; 335 (7615): 343-6.

3. Dale AM, Harris-Adamson C, Rempel D. Prevalence and incidence of carpal tunnel syndrome in US working populations: pooled analysis of six prospective studies. Scand J Work Environ Health. 2013; (39): 495-505.

\section{Литература}

1. Hagert E. Clinical diagnosis and wide-awake surgical treatment of proximal median nerve entrapment at the elbow: a prospective study. Hand (NY). 2013; 8 (1): 41-46.

2. Bland JD. Carpal tunnel syndrome. BMJ. 2007; 335 (7615): 343-6.

3. Dale AM, Harris-Adamson C, Rempel D. Prevalence and incidence of carpal tunnel syndrome in US working populations: pooled analysis of six prospective studies. Scand J Work Environ Health. 2013; (39): 495-505.

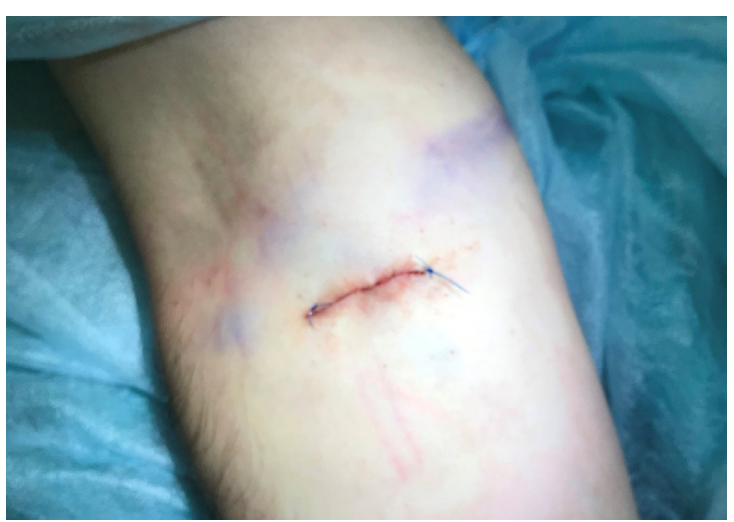

Fig. 6. Postoperative wound

4. Miller DW, Hahn JF. Chapter 1: General methods of clinica examination. Neurological Surgery, 4th edition. W.B. Saunders Company, 1996; p. 31-32.

5. Cheng CJ, Mackinnon-Patterson B, Beck JL, Mackinnon SE. Scratch collapse test for evaluation of carpal and cubital tunnel syndrome. J Hand Surg Am. 2008; 33 (9): 1518-24.

6. Hagert E, Curtin C. Failed Carpal tunnel release: Recognizing the Lacertus syndrome. Problems in hand surgery. 2020: 87-90.

4. Miller DW, Hahn JF. Chapter 1: General methods of clinical examination. Neurological Surgery, 4th edition. W.B. Saunders Company, 1996; p. 31-32.

5. Cheng CJ, Mackinnon-Patterson B, Beck JL, Mackinnon SE. Scratch collapse test for evaluation of carpal and cubital tunnel syndrome. J Hand Surg Am. 2008; 33 (9): 1518-24.

6. Hagert E, Curtin C. Failed Carpal tunnel release: Recognizing the Lacertus syndrome. Problems in hand surgery. 2020: 87-90. 